\title{
Fruits and Vegetables Consumption among Farm Households in Meghalaya: An Empirical Study
}

\author{
Baiarbor Nongbri*, Ram Singh, Sheikh Mohammad Feroze and Singyala Chiphang
}

Central Agricultural University-Imphal, Umiam, Meghalaya, India

*Corresponding author

\section{A B S T R A C T}

\begin{tabular}{|c|}
\hline Keywords \\
\hline $\begin{array}{l}\text { Fruits and } \\
\text { Vegetables } \\
\text { Consumption, } \\
\text { Farm Households }\end{array}$ \\
\hline Article Info \\
\hline $\begin{array}{l}\text { Accepted: } \\
22 \text { June } 2020 \\
\text { Available Online: } \\
10 \text { July } 2020\end{array}$ \\
\hline
\end{tabular}

It was universally known that in the Indian diet, cereals and millets as well as pulses and legumes do provide minerals like calcium and iron yet, vegetables and fruits were also the major sources of minerals, vitamins and fibre and households tends to neglect their importance in the daily consumption. NSSO (2014) report revealed that average monthly per capita consumer expenditure (MPCE) for Indian citizen stood at ₹ 1984 in urban area and ₹ 1054 in rural India with a share of only ₹ 175.2 (urban area) and Rs 112.9 (rural area) in fruits and 175.2 (urban area) and Rs 112.9 (rural area) in terms of vegetables. Thus, fruits and vegetables constituted a minor portion of 10.7 per cent (rural) and 8.8 per cent (urban) MPCE. The present paper emphasised on the availability of fruits and vegetables and the gap in the calorie intake of fruits and vegetables among households. Meghalaya was chosen purposively as the area of the study as the state has the highest prevalence to acute malnutrition and has the highest number of stunting children in the country. The state has also the least per capita per day intake of energy which was only $1,686 \mathrm{Kcal}$ in the rural areas and 1,755 Kcal per capita at urban area day in Meghalaya of the $2400 \mathrm{Kcal}$ as prescribed by the ICMR. A total of three districts viz., East Khasi Hills District, West Jaintia hills and West Garo Hills district have been studies with two blocks each with 2 village from each block. 240 farmers were interviewed and the result was documented. It has been found that the availability of fruits and vegetables to the households were mainly from their own farms and market access. In terms of calorie intake among fruits and vegetables it has been found that across each districts, there was a deficit or gap in the calorie intake by $324.71,308.84$ and $294.78 \mathrm{Kcal}$, respectively with an average deficit by $309.45 \mathrm{Kcal}$ in the state. The study suggests that proper awareness by concerns department had to be initiated towards the importance of fruits and vegetables in the daily diet. As the topography of the state is very suitable for fruits and vegetables, a cluster approach in the development of appropriate crops for certain areas has to be set off by the horticulture institutions for the welfare of the farmers and the farming households as a whole.

\section{Introduction}

Food is the basic necessity of any living being, to survive and to sustain. It is imperative to create and enforce legal entitlements and obligations to ensure that every person is assured of adequate food as it is necessary to lead an active and healthy life 
(Aubree, 2006). Consumption on the other hand can be defined as the economic activity performed by any household (Mor and Sethia, 2018). In order to comprehend for a living, every individual needs food, shelter and clothing. In this context, food and its consumption pattern and availability has been discussed in this paper. It was universally known that in the Indian diet, cereals and millets as well as pulses and legumes do provide minerals like calcium and iron (Rao, 2002), yet, vegetables and fruits were also the major sources of minerals, vitamins and fibre (Rao, 2012) and households tends to neglect their importance in the daily consumption. NSSO (2014) report revealed that average monthly per capita consumer expenditure (MPCE) for Indian citizen stood at ₹ 1984 in urban area and ₹ 1054 in rural India with a share of only ₹ 175.2 (urban area) and Rs 112.9 (rural area) in fruits and 175.2 (urban area) and Rs 112.9 (rural area) in terms of vegetables. Thus, fruits and vegetables constituted a minor portion of 10.7 per cent (rural) and 8.8 per cent (urban) MPCE. As compared to the previous NSSO survey (1990, 2010) of 1987-88 and 2007-08, the share of fruits and vegetables in consumer expenditure has not been improved. It was reported that fruits total share was 10.7 per cent during 1987-88 and 15.7 percent during 2007-08 in rural area and for vegetables it was 13.9 per cent during $1987-88$ to 16.6 percent during 2007-08 in urban India. Fruits and vegetables provide a diversified, flavoured, colourful, tasty, low caloric, and protective, micro-nutrient rich diet (Sachdeva, 2013).

Prima facie, it has been contended that fruits and vegetables were still another challenge in consumption context. The general recommendation for intake of fruits and vegetables was at least 400 grams per person per day (five serving of $80 \mathrm{~g}$ each day) or about $146 \mathrm{~kg}$ per person per year (FAO,
2010). Imperative to the fact that fruits and vegetables held important constituents in the daily food basket, the paper concentrates on the availability of fruits and vegetables and the gap in calorie intake across of these two items towards each household.

\section{Materials and Methods}

Meghalaya has been chosen purposively as the area of study. According to the $68^{\text {th }}$ round of the National Sample Survey on Consumer Expenditure conducted in 2011-12, the per capita intake of calories and protein was reported to be the least in the country with only $1703 \mathrm{Kcal}$. It emphasised that the intake has been declining over the years (Shadap and Pala, 2017). The Comprehensive National Nutrition Survey conducted during the years 2016-18 reported that Meghalaya has the highest prevalence to acute malnutrition and has the highest number of stunting children in the country. The Food and Nutrition Security Analysis (GoI, 2019) reported that across sates, the per capita per day intake of energy was 1,686 Kcal in the rural areas and 1,755 Kcal per capita at urban area day in Meghalaya which was one of the least in the country. Meghalaya per capita per day intake for energy was also comparatively low than national level RDA. The state has three major tribes, the Khasi, Jaintia and the Garo. Three districts viz., East Khasi, West Garo Hills and West Garo Hills districts were selected purposively based on the dominance of the tribes' population in the respective regions. From each districts, two blocks each were selected purposively based on the epoch of establishments of the blocks. Mawphlang and Mylliem blocks were selected from East Khasi Hills, Laskein and Thadlaskein from West Jiantia Hills and Dadengiri and Rongram from West Garo Hills districts, respectively. From Mawphlang block, Wahnongkseh and Lynkien villages were selected randomly and from Mylliem block 
two villages were selected namely Mylliem and Mawklot. From Laskein block, Laskein village and Shangpung village were selected and from Thadlaskein, mookyndur and khliehtyrshi were selected. From Dadengiri block Dadenggre and Abokgre village were selected and from Rongram block, Rongdangree and Sampalgre villages were slected making a total of 6 blocks and 12 villages. A total of 240 farmers were interviewed using pre-tested schedules. To understand the food availability, the primary data were collected seasonally viz., premonsoon, monsoon and post-monsoon where May, September and December months were selected using pre tested schedule during 2018 and 2019. The secondary data on area, yield and production of the main crops, the main schemes adopted and adhered were collected from the published journals, government institutions like District Commissioner offices, Directorate of Agriculture and Horticulture and Directorate of Rural Development Agency and from various publications of the Central government and the Government of Meghalaya etc.

To study the food availability, a food basket has been formulated. The monthly food baskets consist of a set of foods that are typically consumed by households in the particular area and make up 67 to 88 percent of total calories consumed by the average household (Cochrane and D'Souza, 2015). From the food basket, a number of food crop/items were picked up for the study. A tabular presentation and charts were used to understand the objectives.

To understand the the gap in calorie intake, the difference of requirement and consumption of calories has been calculated using the calorie conversion adopted by Gopalan et al., (1980). The method used in computing the gaps in calories was given as
Calories Gap = CA - CR $($ Singh and Datta, 2016)

Where, $\mathrm{CA}=$ Calories available from the item consumed, i.e., sum of the calories of each product, which household consumed and $\mathrm{CR}=$ Calories requirement normative requirement of the calories (as per ICMR standards).

\section{Results and Discussion}

\section{Availability of fruits and vegetables the households}

The state was rich in a variety of fruits. Some of the fruits mostly consumed and locally available over the years were carambola which was available during March-april, Soh ramdieng (Baccaurea sapida) during MayJuly, sohkwit (C. macroptera) during October-November, Sohmylleng during December January, strawberry during February to March sohshang (Elaeagnus latifolia) during March-April, sohphie (Myrica esculenta) during March April, peach and pears during April to May, passion fruit or soh brap during June-September, Sohiong (Prunus nepalensis) during June-August and soh shur (Pyrus pashia) during DecemberJanuary. The other fruits mostly consumed were mango and banana (GoM, 2018). Among all the crops available, Banana, pineapple and mandarin were taken into consideration as they were mostly consumed across all the districts. Banana had an average area of 6457.59 ha during 2000-01 to 2016-17 and an average production of $76734.24 \mathrm{MT}$ during the same period in the state. The CAGR was calculated to increase significantly in terms of area and production by 2.00 and 2.54 per cent during 2000-01 and 2016-17. In terms of pineapple which is one of the main fruit crop in the state, the average area and production was 12162 ha and 11589 MT respectively, during 2000-01 to 2016-17. The CAGR was calculated to be significantly 
increased over the years in terms of area by 1.7 per cent but there was a decline in the production by 0.85 per cent during 2000-01 to 2016-17. Meghalaya was also a home to many citrus fruits with Khasi Mandarin being the worldwide known fruit crop. The average area and production among the citrus fruits were 9805.76 ha and 41378.24 MT, respectively with a significant increase in the growth over the years in terms of both area and production by 2.89 and 3.3 per cent, respectively (Table 1).

\section{Area and production of Vegetables}

The Government of Meghalaya in their recent report claimed that the total area of vegetables in the state was 19581 ha and 19824 ha during 2016-17 and 2017-18, respectively with an average production of 271 and 274 thousand MT during 2016-17 and 2017-18, respectively (GoM, 2019). Vegetables has been obtained to the households through own farm productions and market. In the present exploration, three types of vegetables have been taken into consideration based on the three season domains of consumption among the households. The main vegetables mainly consumed were cabbage during pre-monsoon, beans at monsoon and mustard at post monsoon periods. The production however during the 2010-11 to 2017-2018, has been calculated as 41354.4, 6546.5 and 2520.75 metric tonnes, respectively for cabbage, beans and mustard (GoM, 2018).

\section{East Khasi Hills District}

\section{Fruits}

At household level, different types of fruits were consumed across all seasons. However, banana, pineapple and mandarin were mostly consumed by the respondents. Banana was mostly available through own farms and kitchen garden. However, pineapple was mostly available to the market. During post monsoon, the households reported that mandarin was mostly consumed and made available to the households. The average availability of fruits per month per person across each household was reported to be 0.61 $\mathrm{kg}$ (Table 2). The average fruits availability across each households through own farm was $1.36 \mathrm{~kg}$ and maximum contribution was through market sources with $2.52 \mathrm{~kg}$ per household per month across each seasons (Fig. 1).

\section{Vegetables}

Vegetables or jhur as locally called has been obtained from own farm and market across each households. The average availability per households across each season for cabbage, beans and mustard has been calculated to be 3.36, 3.19 and $2.19 \mathrm{~kg}$ per households per month through their own farms across all seasons. The market availability across seasons was 3.46, 3.44 and $2.26 \mathrm{~kg}$, respectively (Table 3). Overall, the households were met with $3.28 \mathrm{~kg}$ per month from their own fields and the maximum contribution was through markets with 3.43 $\mathrm{kg}$ per month across each season (Fig.2).

\section{West Jaintia Hills}

\section{Fruits}

The fruits that were available in the district were banana, pineapple and mandarin during pre-monsoon, monsoon and post monsoon periods. The availability of these fruits were from own farm and market except pineapple where the availability was mainly through market. During pre-monsoon, the accessibility of households towards banana were $2.00 \mathrm{~kg}$ through own farm and $2.3 \mathrm{~kg}$ through market. During monsoon and post monsoon, the availability of pineapple were $2.59 \mathrm{~kg}$ from market and for mandarin it was $2.08 \mathrm{~kg}$ and 
$2.49 \mathrm{~kg}$ through own farm and market simultaneously, across each households (Table 4). The maximum access for fruit availability to the households was through market with $2.48 \mathrm{~kg}$ per households per month (Fig. 3).

\section{Vegetables}

The vegetable consumption at Khasi Hills districts and West Jaintia Hills district was more or less the same. The households mostly consumed cabbage, beans and mustard during Pre-Monsoon, Monsoon and post monsoon, respectively. The availability of these vegetables across different seasons from their own farms was $3.97 \mathrm{~kg}, 3.71 \mathrm{~kg}$ and $3.81 \mathrm{~kg}$. Through market, the vegetables availability was $3.93 \mathrm{~kg}, 3.97 \mathrm{~kg}$ and $3.88 \mathrm{~kg}$ across different seasons. The average availability per person per month was $1.26 \mathrm{~kg}$ (Table 3.5). Market access contributed the maximum towards vegetables availability with $3.92 \mathrm{~kg}$ per household per month (Fig. 4).

Table.1 Trends in area and production of banana, pineapple and citrus fruits in Meghalaya

\begin{tabular}{|c|c|c|c|c|c|c|}
\hline Fruits & \multicolumn{2}{|c|}{ Banana } & \multicolumn{2}{c|}{ Pineapple } & \multicolumn{2}{c|}{ Citrus fruits } \\
\hline Years & Area & Production & Area & Production & Area & Production \\
\hline $\mathbf{2 0 0 0 - 0 1}$ & 5377 & 64100 & 9235 & 81723 & 8089 & 32311 \\
\hline $\mathbf{2 0 0 1 - 0 2}$ & 5311 & 63733 & 9315 & 82398 & 8043 & 34668 \\
\hline $\mathbf{2 0 0 2 - 0 3}$ & 5344 & 65659 & 9839 & 83333 & 7987 & 32791 \\
\hline $\mathbf{2 0 0 3 - 0 4}$ & 5658 & 66875 & 9480 & 91671 & 8046 & 36636 \\
\hline $\mathbf{2 0 0 4 - 0 5}$ & 6276 & 67875 & 9565 & 92036 & 9808 & 38989 \\
\hline $\mathbf{2 0 0 5 - 0 6}$ & 6426 & 71695 & 10135 & 93625 & 8871 & 36893 \\
\hline $\mathbf{2 0 0 6 - 0 7}$ & 6422 & 72366 & 10112 & 96812 & 8845 & 37139 \\
\hline $\mathbf{2 0 0 7 - 0 8}$ & 6380 & 72207 & 9808 & 94170 & 9123 & 37579 \\
\hline $\mathbf{2 0 0 8 - 0 9}$ & 6522 & 74314 & 10523 & 102506 & 9368 & 37702 \\
\hline $\mathbf{2 0 0 9 - 1 0}$ & 6802 & 78822 & 10542 & 103432 & 9784 & 39070 \\
\hline $\mathbf{2 0 1 0 - 1 1}$ & 6795 & 79954 & 10607 & 104130 & 9885 & 38817 \\
\hline $\mathbf{2 0 1 1 - 1 2}$ & 6919 & 82125 & 10766 & 106168 & 9997 & 39315 \\
\hline $\mathbf{2 0 1 2 - 1 3}$ & 6992 & 83988 & 10816 & 109393 & 10146 & 44896 \\
\hline $\mathbf{2 0 1 3 - 1 4}$ & 7039 & 86432 & 11314 & 117767 & 11813 & 50914 \\
\hline $\mathbf{2 0 1 4 - 1 5}$ & 7112 & 88709 & 11577 & 123126 & 12044 & 52851 \\
\hline $\mathbf{2 0 1 5 - 1 6}$ & 7162 & 91308 & 11874 & 13264 & 12291 & 55095 \\
\hline $\mathbf{2 0 1 6 - 1 7}$ & 7242 & 94320 & 12162 & 11589 & 12558 & 57764 \\
\hline Average & 6457.59 & 76734.24 & 10451.18 & 88655.47 & 9805.76 & 41378.24 \\
\hline CAGR & $2.00 * * *$ & $2.54 * * *$ & $1.7 * * *$ & -0.85 & $2.89 * * *$ & $3.3 * * *$ \\
\hline
\end{tabular}

(GoM, 2019)

Table.2 Fruits availability from different sources in East Khasi Hills District (in Kg)

\begin{tabular}{|l|r|r|r|}
\hline Particulars & Own farm & Market & Average availability per person per month \\
\hline Pre-Monsoon & 2.00 & 2.32 & \\
\hline Monsoon & 0.00 & 2.51 & 0.61 \\
\hline Post-Monsoon & 2.09 & 2.72 & \\
\hline Average & 1.36 & 2.52 & \\
\hline
\end{tabular}


Table.3 Vegetable availability from different sources in East Khasi Hills District (in Kg)

\begin{tabular}{|l|l|l|c|}
\hline Particulars & Own farm & Market & Average availability per person per month \\
\hline Pre-Monsoon & 3.36 & 3.46 & \multirow{2}{*}{1.06} \\
\hline Monsoon & 3.19 & 3.44 & \\
\hline Post-Monsoon & 2.19 & 2.26 & \\
\hline Average & 3.28 & 3.43 & \\
\hline
\end{tabular}

Table.4 Fruits availability from different sources in West Jaintia Hills District (in Kg)

\begin{tabular}{|l|c|c|c|}
\hline Particulars & Own farm & Market & Average availability per person per month \\
\hline Pre-Monsoon & 2.00 & 2.36 & 0.62 \\
\hline Monsoon & 0.00 & 2.59 & \\
\hline Post-Monsoon & 2.08 & 2.49 & \\
\hline & & & \\
\hline Average & 1.36 & 2.48 & \\
\hline
\end{tabular}

Table.5 Vegetables availability from different sources in West Jaintia Hills District (in Kg)

\begin{tabular}{|l|l|l|l|}
\hline Particulars & Own farm & Market & Average availability per person per month \\
\hline Pre-Monsoon & 3.97 & 3.93 & \multirow{2}{*}{1.26} \\
\hline Monsoon & 3.71 & 3.97 & \\
\hline Post-Monsoon & 3.81 & 3.88 & \\
\hline Average & 3.83 & 3.92 & \\
\hline
\end{tabular}

Table.6 Fruits availability from different sources in West Garo Hills District (in Kg)

\begin{tabular}{|c|r|r|c|}
\hline Particulars & Own farm & Market & Average availability per person per month \\
\hline Pre-Monsoon & 2.84 & 2.30 & 0.78 \\
\hline Monsoon & 2.39 & 2.69 & \\
\hline Post-Monsoon & 2.10 & 2.51 & \\
\hline
\end{tabular}

Table.3.7 Vegetables availability from different sources in West Garo Hills District (in Kg)

\begin{tabular}{|c|r|r|c|}
\hline Particulars & Own farm & Market & Average availability per person per month \\
\hline Pre-Monsoon & 3.73 & 3.54 & 1.06 \\
\hline Monsoon & 3.30 & 2.96 & \\
\hline Post-Monsoon & 3.20 & 3.15 & \\
\hline
\end{tabular}


Table.8 Average quantity consumed per person per month across different households in different districts (in $\mathrm{Kg}$ )

\begin{tabular}{|c|c|c|c|c|c|c|}
\hline SI.No & \multicolumn{2}{|c|}{ Food items } & East Khasi & West Jaintia & West Garo & Meghalaya \\
\hline 1. & \multirow[t]{3}{*}{ Fruits } & Banana & 0.68 & 0.71 & 0.96 & 0.70 \\
\hline 2. & & Pineapple & 0.40 & 0.42 & 0.86 & 0.56 \\
\hline 3. & & Mandarin & 0.76 & 0.76 & 0.95 & 0.75 \\
\hline 4. & \multirow{3}{*}{$\begin{array}{c}\text { Vegetab } \\
\text { les }\end{array}$} & Cabbage & 1.08 & 1.28 & 1.35 & 1.24 \\
\hline 5. & & Beans & 1.05 & 1.25 & 1.17 & 1.16 \\
\hline 6. & & Mustard & 1.5 & 1.25 & 1.18 & 1.31 \\
\hline Total & & & 0.18 & 0.19 & 0.15 & 0.19 \\
\hline
\end{tabular}

Table.9 Average Calories contributed by different food items across various districts (Kcal/day)

\begin{tabular}{|c|c|c|c|c|c|c|}
\hline Sl.No & \multicolumn{2}{|c|}{ Food items } & $\begin{array}{l}\text { East Khasi } \\
\text { Hills }\end{array}$ & $\begin{array}{l}\text { West Jaintia } \\
\text { Hills }\end{array}$ & $\begin{array}{l}\text { West Garo } \\
\text { Hills }\end{array}$ & Meghala \\
\hline 1. & \multirow[t]{3}{*}{ Fruits } & Banana & 18.57 & 21.26 & 24.65 & 21.49 \\
\hline 2. & & Pineapple & 9.73 & 10.3 & 11.55 & 10.53 \\
\hline 3. & & Mandarin & 6.65 & 6.89 & 14.97 & 9.50 \\
\hline 4. & \multirow{3}{*}{$\begin{array}{l}\text { Vegetab } \\
\text { les }\end{array}$} & Cabbage & 10.25 & 13.47 & 14.3 & 12.67 \\
\hline 5. & & Beans & 17.69 & 23.12 & 23.14 & 21.32 \\
\hline 6. & & Mustard & 12.4 & 16.12 & 16.61 & 15.04 \\
\hline Total & & & 75.29 & 91.16 & 91.16 & 90.55 \\
\hline Gap & & & -324.71 & -308.84 & -294.78 & -309.45 \\
\hline
\end{tabular}

Fig.1 Fruits availability from different sources in East Khasi Hills District (in $\mathrm{Kg}$ )

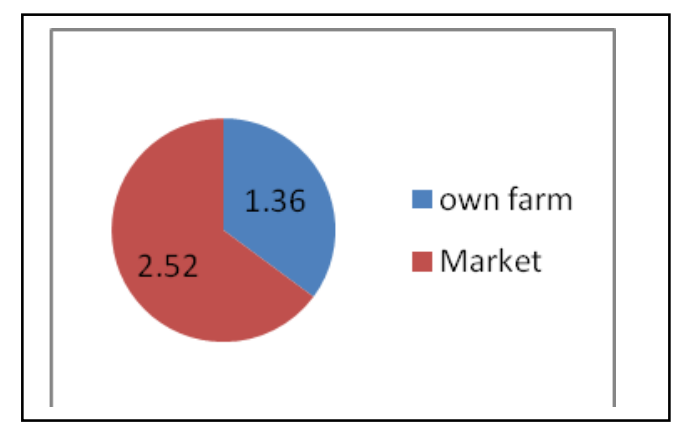

Fig.2 Vegetables availability from different sources in East Khasi Hills District (in Kg)

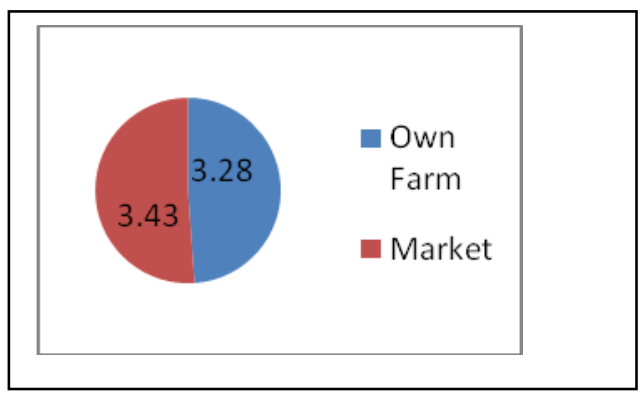


Fig.3.3 Fruits availability from different sources in West Jaintia Hills District (in Kg)

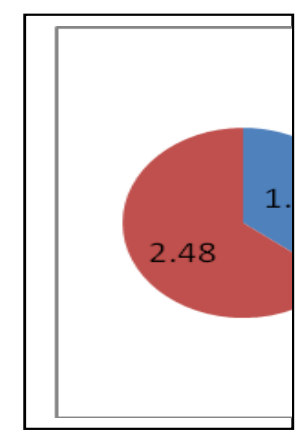

Fig.3.4 Vegetables availability from different sources in West Jaintia Hills District (in $\mathrm{Kg}$ )

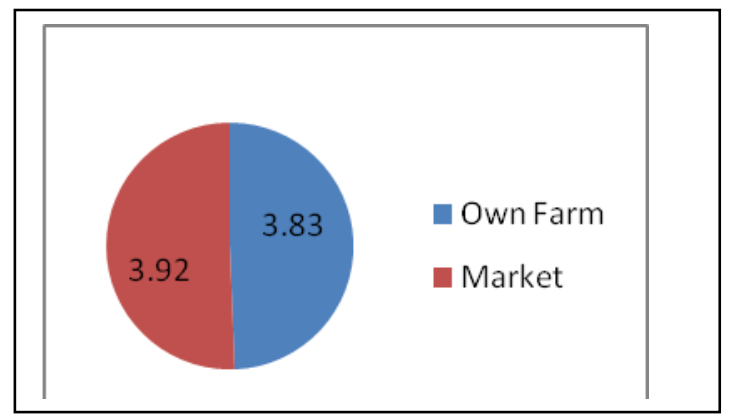

Fig.3.5 Fruits availability from different sources in West Garo Hills District (in Kg)

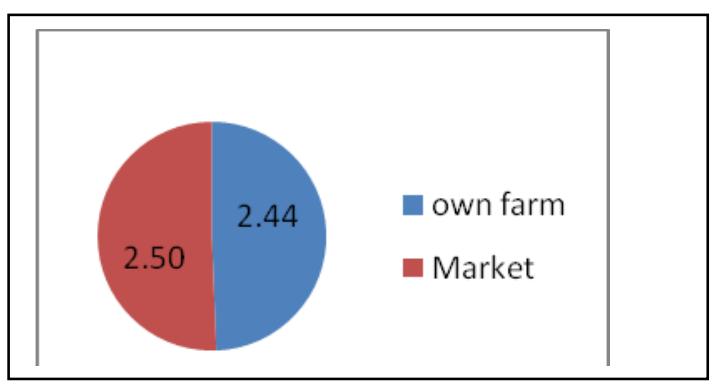

Fig.3.6 Milk availability from different sources in West Garo Hills District (in Kg)

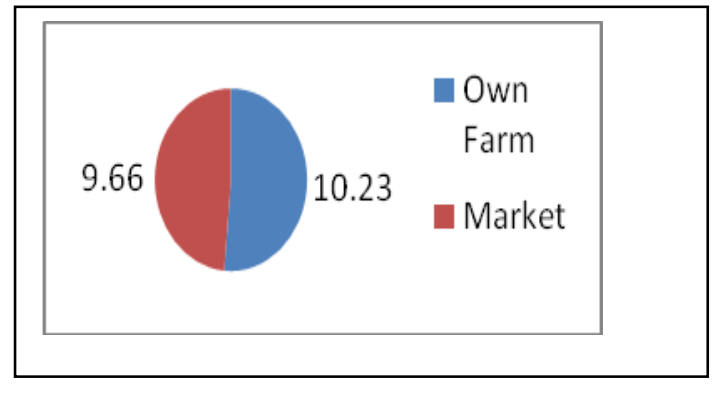




\section{West Garo Hills district}

\section{Fruits}

Garo hills district has different types of fruits gown in their region. The main fruits were banana, mango, plums, pineapple, citrus fruits like mandarin, pumelo etc,.The fruits that were available in the district were banana, pineapple and mandarin during pre-monsoon, monsoon and post monsoon periods. The availability of these fruits were from own farm and market except mango where the availability was mainly through market. During pre-monsoon, the accessibility of households towards banana were $2.00 \mathrm{~kg}$ through own farm and $2.3 \mathrm{~kg}$ through market. During monsoon and post monsoon, the availability of mango were $2.59 \mathrm{~kg}$ from market and for mandarin it was $2.08 \mathrm{~kg}$ and $2.49 \mathrm{~kg}$ through own farm and market simultaneously, across each households (Table 6) (Fig. 5)

\section{Vegetables}

The Garo households mostly consumed varieties of vegetables across different seasons. The most common vegetables consumed across each household were cabbage, beans and mustard during PreMonsoon, Monsoon and post monsoon, respectively. Vegetables were made available through two important sources viz., own farm and market. The average availability during pre-monsoon, monsoon and post-monsoon were $3.73,3.30$ and $3.20 \mathrm{~kg}$ per households per month. It has been calculated that the average availability of vegetables per individual and across each households was $1.06 \mathrm{~kg}$ per month (Table 7). (Fig. 6)

\section{The gap in calorie intake}

In terms of fruits consumption, on an average, the intake of banana during pre monsoon period by an individual per month was 0.68 $\mathrm{kg}, 0.71$ and $0.96 \mathrm{~kg}$, respectively. Banana was mainly consumed during this season as it was a peak season across all districts. Pineapple on the other hand was available in abundance and mainly consumed during monsoon period with an average consumption of 0.56 across each district. Whereas, during post monsoon period, mandarin or Khasi mandarin was mostly consumed across all districts with an average consumption of 0.76 $\mathrm{kg}$ each and $0.95 \mathrm{~kg}$, at East Khasi hills, west Jaintia and west Garo hills districts, respectively. On an average, $0.75 \mathrm{~kg}$ fruits have been consumed by an individual per month across each district.

The average intake of cabbage was $1.08 \mathrm{~kg}$, $1.28 \mathrm{~kg}$ and $1.35 \mathrm{~kg}$ in East Khasi Hills, Jaintia hills and west Garo Hills district, respectively. Overall, in Meghalaya, on average an individual consumed $1.24 \mathrm{~kg}$ of cabbage per month during pre-monsoon period when there was a boom harvest in terms of cabbage. During post monsoon, beans were prevalent in the study area and during the peak season, consumer consumed $1.16 \mathrm{~kg}$ across Meghalaya with an average consumption of $1.05,1.25$ and $1.17 \mathrm{~kg}$ at East Khasi Hills, Jaintia hills and west Garo Hills district, respectively. Post monsoon period was rich in mustard of which the households mostly consumed mustard above other vegetables with an average consumption per individual of $1.5,1.25$ and $1.18 \mathrm{~kg}$, respectively across each district. By and large, $0.19 \mathrm{~kg}$ per person per month has been consumed by an individual in Meghalaya

Although, varieties of fruits and vegetables has been consumed across each districts, but, on an average, the average calories consumed across East Khasi hills, West Khasi Hills and West Garo hills district was 75.29, 91.16 and $91.16 \mathrm{Kcal} /$ day. According to the FAO, an average requirement advised was about 
$400 \mathrm{Kcal}$ per individual per day of which, there was a deficit in the consumption by 324.71, 308.84 and 294.78 Kcal. Overall, there was a deficit by $309.45 \mathrm{Kcal}$ in terms of consumption.

In conclusion the objectives of this paper emphasised on two main objectives, the availability of food fruits and vegetables to the households and the calorie intake provided to an individual per day. It has been found that a household mostly avail fruits and vegetables through their own farms and market. It has also been found that there was a large gap in the calorie intake among individuals across each district in the state. Thus, it is advised that proper awareness by the concern departments on the food intake and the importance of fruits and vegetables to the households has to be the priority. The state has already suffered from prevalence to acute malnutrition and stunting, hence it is required that the households should be the main priority of teaching towards the food consumption and the importance of fruits and vegetables in their daily diet. As the topography of the state is very suitable for fruits and vegetables, a cluster approach in the development of appropriate crops for certain areas has to be set off by the horticulture institutions for the welfare of the farmers and the farming households as a whole.

\section{References}

Aubree, A. 2006. Exploring the Drivers of and Barriers to more Sustainable Food Supply Chains, M.Sc. Thesis, Cranfield University.

Cochrane, N. and D'Souza, A. 2015. Measuring Access to Food in Tanzania: A Food Basket Approach. Economic Research Service. Economic Information Bulletin Number 135. United States Department of Agriculture.
FAO. 2010. The state of food insecurity in the world. Addressing food insecurity in protracted crises. Food and Agriculture Organisation, Rome.

GoM. 2018. Statistical handbook of Meghalaya. Directorate of Economics and Statistics. Government of Meghalaya, Shillong.

GoM. 2019. Statistical handbook of Meghalaya. Directorate of Economics and Statistics. Government of Meghalaya, Shillong.

Gopalan, C., Sastri, R.B.V., and Balasubramanian, S.C. 1980. Nutritive values of Indian foods. 3rd Edition, Indian Council of Medical Research, New Delhi.

NSSO. 2014. Key Indicators of Situation of Agricultural Households in India. National Sample Survey Organization, Ministry of Statistics and Programme Implementation (MOSPI), Government of India, New Delhi.

Mor, K. and Sethia, S. 2018. Changing Consumption Basket in Rural and Urban Areas- A Journey from Conventional Food to Convenience Food. Pacific Business Review International. 10 (10): 29-39.

NSSO. 1990. Household Consumer Expenditure in India, 1987-88. National Sample Survey Organization, Ministry of Statistics and Programme Implementation (MOSPI), Government of India, New Delhi.

NSSO. 2010. Household Consumer Expenditure in India, 2007-08. National Sample Survey Organization, Ministry of Statistics and Programme Implementation (MOSPI), Government of India, New Delhi.

NSSO. 2014. Key Indicators of Situation of Agricultural Households in India. National Sample Survey Organization, Ministry of Statistics and Programme Implementation (MOSPI), Government 
of India, New Delhi.

Rao, B.S.N. 2002. Pulses and legumes as functional foods, Nutrition Foundation of India Bulletin. 23(1):1-4.

Rao, B.S.N. 2012. Millets in Indian Diets. An overview, Nutrition Foundation of India Bulletin. 33 (3): 1-7.

Sachdeva,S., Sachdev, T.R., and Sachdeva, R. 2013. Increasing Fruit and Vegetable Consumption: Challenges and Opportunities. Indian J.Community
Med. 38(4): 192-197.

Shadap, A. M. W. K. and Pala, V. 2017. Nutritional intake and consumption pattern in the states of Himachal Pradesh and Meghalaya.The NEHU Journal, 2, 15-28.

Singh, S.R., and Datta, K.K. 2016. Farm household food security in India. Indian J. Econ. Dev., 12 (1): 15-23.

\section{How to cite this article:}

Baiarbor Nongbri, Ram Singh, Sheikh Mohammad Feroze and Singyala Chiphang. 2020. Fruits and Vegetables Consumption among Farm Households in Meghalaya: An Empirical Study. Int.J.Curr.Microbiol.App.Sci. 9(07): 3628-3638. doi: https://doi.org/10.20546/ijcmas.2020.907.423 